\title{
The First ALS Ambulance in the World
}

\author{
Peter Felkai ${ }^{*}$, Gabor Debrődi²
}

${ }^{1}$ SOS Hungary Medical Service, Budapest, Hungary

${ }^{2}$ Hungarian National Emergency Service, Kresz Géza Rescue Museum, Budapest, Hungary

Corresponding Author: Peter Felkai, MD, PhD, Associate Professor, Medical Director, SOS Hungary Medical Service, Szentendrei ut 301, Budapest, H-1039, Hungary. Email: peter.felkai@soshungary.hu

Received August 10, 2017; Accepted October 16, 2017; Online Published November 14, 2017

\begin{abstract}
The survival rate of medical emergencies depends highly on the intervention time and prompt medical care on the scene. The idea of "bring the doctor and medical equipment to the spot" was born in Hungary in the mid-1950s. The demand for advanced life support was a consequence of the fast growth of industry and traffic. It is worthwhile to review the development of the idea, the therapeutic methods, and the devices used by medical emergency and rescue services based on the example of the Hungarian model. What based on the highly trained medical team and the state-of-art medical devices respectively. In this study, the researchers collected and described the contemporary memorabilia of the Hungarian Emergency Services and compared them with the existing ideas and ambulance types in the world. The basic ideas and their adaptation into practice are also reviewed. The increasing demand for the soonest possible medical treatment can be claimed the reason for special ambulances with special teams and equipment. The all-purpose ambulance proved to be the most appropriate solution to the problem. The first ambulance of this kind was first used in Hungary.

Keywords: ALS Ambulance, Rescue, Emergency Service, Patient Transport, History of Medicine
\end{abstract}

Citation: Felkai P, Debrődi G. The first ALS ambulance in the world. Int J Travel Med Glob Health. 2017;5(4):113-118. doi:10.15171/ijtmgh.2017.23.

\section{Introduction}

After a devastating world war, the second one during the course of the 20th century, European countries, both winners and losers alike, were still in ruins. To reconstruct their normal ways of life, all nations tried to speed up the growth of their economy, agriculture, industrialization, and transportation. Unfortunately, some unwanted side effects of these efforts appeared, such as increasing numbers of traffic accidents, industrial injuries, and later the acute cardiac syndromes caused by the challenges of a modern society.

Hospitals tried to measure up to the growing number of acute cases, but the road from the site of the injury to the hospital was usually long and stressful. Picking up the patient on the scene and running with him/her to the hospital (the scoop-and-run method) was the earliest possible attempt at medical help. Surprisingly, patients arrived at the hospital in worse condition than their original medical problem could explain. As for cardiac patients, two-thirds of them died before they could even reach the hospital. The solution was hypothetical: if an ambulance service could bring advanced medical treatment to the scene, maybe patients would gain valuable minutes (stay-and-stabilize method). However, at that time, neither the medical staff nor the medical equipment was prepared for this kind of intervention. The first effective step to preventing further "health-care damages" before arriving at the hospital was taken in Hungary.

\section{Evidence}

Archeological findings have shown that providing first aid was one of the first effective medical interventions from prehistoric times. ${ }^{1,2}$ One can find the roots of the idea and many examples of rescues in the history of medicine: giving first aid on the battlefield, saving the almost drowned victim at the riverside, and performing different forms of early resuscitation attempts. ${ }^{3}$ In the middle ages, a coach was used as a "medical vehicle" to transport sick persons faster. For the transportation of civil patients, the most well-known early attempt can be seen in Florence, Italy in the museum of Fraternitas of Misericordia: an order for transportation of some patients suffering from the plague (Figure 1). This clearly shows that the state tried to establish a public healthcare system.

Methods for attempting the rescue of wounded soldiers from the battlefields are also common knowledge. Napoleon's field surgeon D. J. Larrey created the so-called flying ambulances at the beginning of the 19th century CE. ${ }^{4}$ The invention and development of the petrol engine naturally revolutionized ambulance vehicles. Soon, motorized ambulances appeared.

Copyright $(C 2017$ The Author(s). This is an open-access article distributed under the terms of the Creative Commons Attribution License (http:// creativecommons.org/licenses/by/4.0), which permits unrestricted use, distribution, and reproduction in any medium, provided the original work is properly cited. 


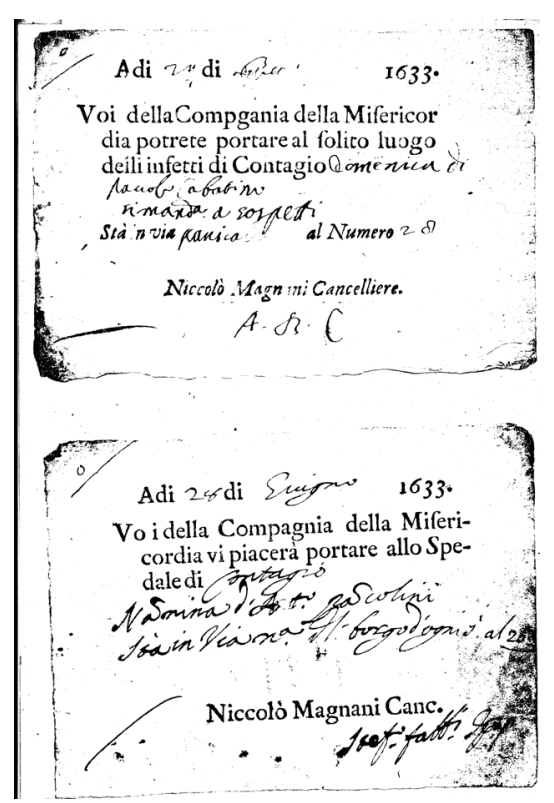

Figure 1. Patient Transportation and Transferal Order From 1633 From the Misericordia di Firenze

In 1899, Michael Reese Hospital in Chicago ${ }^{5}$ acquired the first electric motor-powered ambulance. In Hungary, the first motorized vehicle showed up in 1902 (Figure 2).

This was not so much an ambulance as a "first intervention car". An emergency doctor was transported to the scene, and the horse-coach-driving ambulance met with the doctor there. This method is now called the "rendezvous rescue system".

Demands for a more advanced rescue service always increase when socio-industrial development speeds up, in both America and Europe. In the United States, the frequent smoke-poisoning cases of firemen triggered the establishment of the rapid deployment of a respirator, seen as early as $1915 .^{6}$ After the second world war, rapid industrialization began in European countries, because they were heavily affected by wartime destruction.

Due to the post-war agreements of the Allies, Hungary belonged in the Soviet sphere of interest. Naturally,

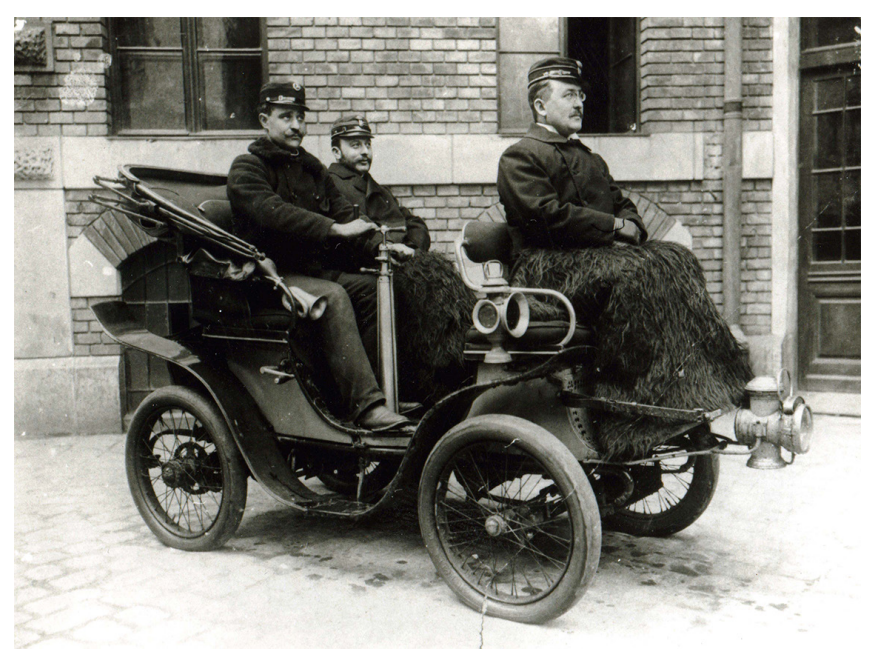

Figure 2. The Hungarian Voluntary Ambulance Service's First Motorized Medical Vehicle, 1902 (Dyon type, 3,5 Le) institutions had to copy the Soviet system; thus, a centralized and monopolized emergency and ambulance system was established. Because of forced industrialization, industrial accidents (mainly electric shock) grew rapidly in number. To provide a faster and more effective treatment (which used to be successful often; for example, in cases of electric injuries), the special service team known as the National Emergency Service (NES) was established. The newly-formed team had four tasks: the first and obvious one was to rescue patients by providing advanced medical first aid on the scene; secondly, to transport the patient by a less stressful manner to the hospital; third, to teach the young generation of emergency doctors; and fourth, to try out the latest rescue devices and methods, including finding the most appropriate car for an emergency ambulance.

In order to fulfill these tasks, the most experienced and ambitious young doctors and medical personnel were selected to staff this new branch of the NES. One of the young doctors, Thomas Felkai, was appointed as chief medical officer of this special service. (Later, he also became the founder the Hungarian Rescue and Ambulance Museum in Budapest.) Numerous meetings were held before the start of this special service, which was baptized the "Storm Ambulance Service" (SAS). Thomas Felkai compiled medical protocols for different emergency situations and carefully studied the literature looking for new medicines and methods in the field of emergency medicine. A detailed observation chart was introduced for medical and scientific research reasons, upon which the on-site and during-transport therapies and interventions applied for the patients were recorded. Since the SAS was intended to treat all kinds of serious emergency cases (Table 1), it was equipped with all the necessary devices, from a pulmotor to a delivery kit. ${ }^{7}$ The recent literature states that the multipurpose, sole-provider, all-advanced life support ambulance service proved extremely effective in the field of prehospital emergency treatment. ${ }^{8}$ Thus, the prototype of this "all-ALS type" of rescue service was born.

In the early 1950s, Hungary lacked almost every modern technical device; new cars and medical tools were even less than rare. Thus, the first emergency ambulance was an Eastern-Germany made IFA Granit Phänomen-type van, the inner space of which was reshaped into an ambulance (Figure 3).

Table 1. Medical Problems by which SAS must be alarmed ("shoot off," in Hungarian ambulancemen's slang)

\begin{tabular}{ll}
\hline Nature of the Emergency & \\
\hline Trauma & Internal \\
\hline Drowning; near-drowning & Hypothermia \\
Submersion & Difficult delivery \\
Strangulation & Poisoning \\
Traffic accident with poly-traumatic injuries & Toxic gas exposure \\
Gun shot & Shortness of breath \\
Hypovolemia (injury, delivery) & Hemorrhage \\
Electric shock & Life-threatening \\
Suicide attempts & conditions \\
Burns $>9 \%$ of BSA & \\
\hline
\end{tabular}




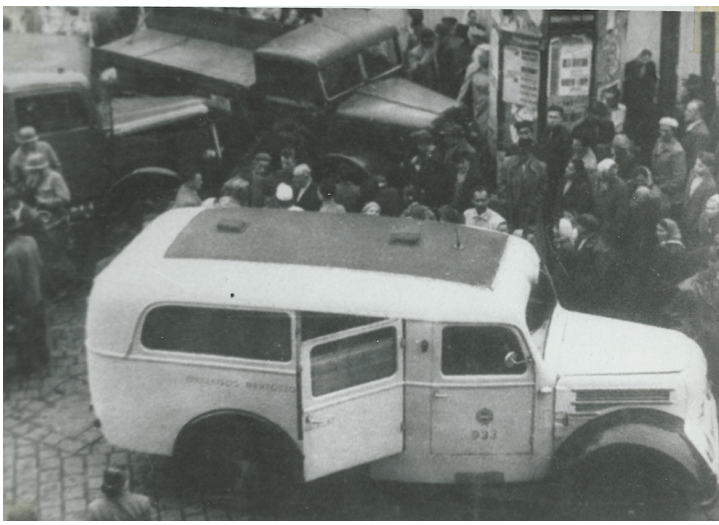

Figure 3. The First Emergency Ambulance in Hungary (IFA Granit 27 Phänomen), 1956.

The special ambulance was equipped with all the up-to-date medical devices and tools available at that time. In addition to large-scale equipment and tools, this first ambulance in Hungary was also equipped with a siren.

During the anti-Soviet revolution in 1956, all special ambulances were destroyed. After the revolution was suppressed, the US-made Dodge Job-Rated ambulance, donated by the International Red Cross, went into service. Some homemade refurbishing was done, and finally, a useful, state-of-the-art, modern emergency ambulance was produced (Figure 4 and Figure 5).

Here it must be noted that this model had a revolving blue light and was equipped with a shortwave radio communications system for the first time in the medical history of Hungary. Later, different vehicle types were tried to determine their suitability for advanced medical on-site first intervention (Figure 6).

All medical experiences were evaluated or firstly elaborated in the NES's own hospital (established in 1956), where a small trauma and internal medicine ward (later ICU) were created. The procedures that were tried by the patient's bedside in the hospital were soon put into practice (Figure 7) on-site as well.

Therefore, contrary to any other emergency system, the NES had a hospital; it was not that a hospital had an ambulance service. Within years, the SAS system was introduced in almost all major towns in Hungary. The realization and establishment of the first rescue vehicle with an emergency doctor on board can be considered the first mobile emergency ambulance in the world. Today, the demand for the centralization of EMS and the physician-on-board idea seems to have returned, ${ }^{9,10}$ mainly in countries facing geographical or climatic difficulties. ${ }^{11}$ The discipline of on-site emergency medicine was called "oxyology" in Hungary.

The first International Emergency Services' Congress in Budapest (1958) approved the Hungarian SAS methods, results, and experiences with advanced medical first aid. This was the triumph of the idea. As a result of the Congress's opinion, the idea of a special emergency ambulance spread worldwide. In different cities of West Germany, a traumatology-oriented emergency ambulance was implemented ${ }^{12,13}$ in response to the increasing number of traffic accidents. The French SMUR (Service Mobile d'Urgence et de Réanimation, 1957)

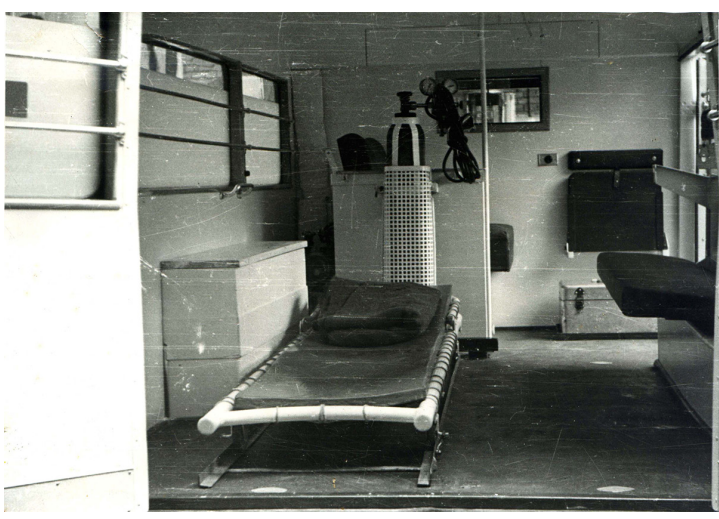

Figure 4. The Second Generation of SAS: Dodge Job-Rated Ambulance.

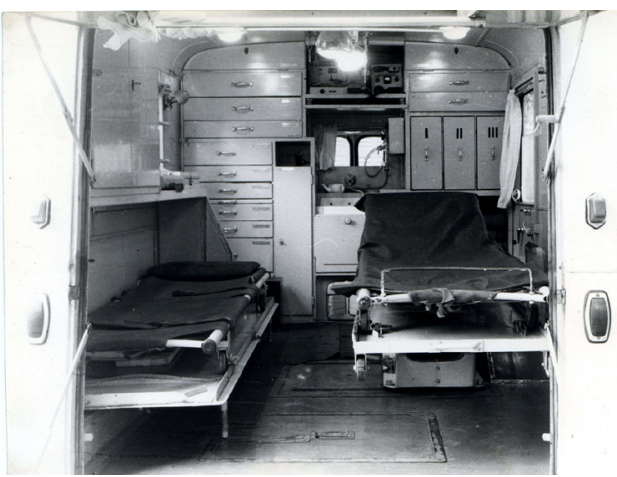

Figure 5. The first version of the SAS (1957) was refurbished in 1960. Two of this type of ambulance remained in charge until 1963.

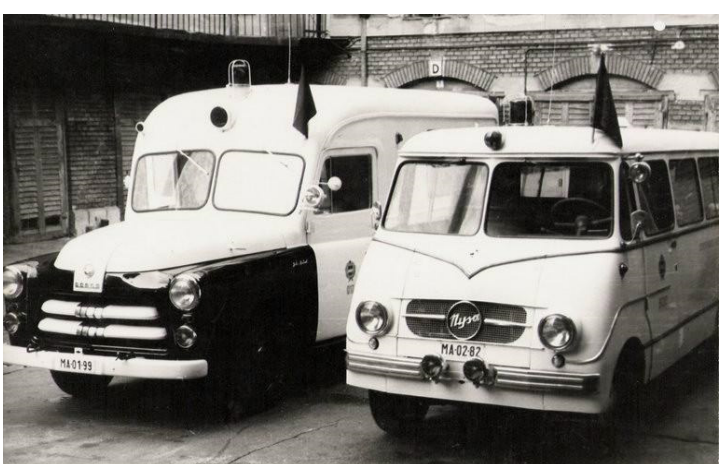

Figure 6. Two Types of SAS Vehicle: Dodge Van R-6 and Nysa N59M (right) in 1959

was dubbed "l'antenne chirurgical," a reference to the young doctors on board who were in constant contact with the senior officer in the hospital ${ }^{14}$ via radio telecommunication.

\section{Discussion}

The timeline of the newly-formed special ambulance services (Table 2) suggests that the first wave of on-site emergency treatments and the establishment of some special ambulance services were triggered by the increasing number of road accidents. In the late 1970s, when more epidemical data had been collected on heart disease and the appropriate treatments and devices were invented, the special services had to provide first aid on-site to victims of myocardial infarction, too. 


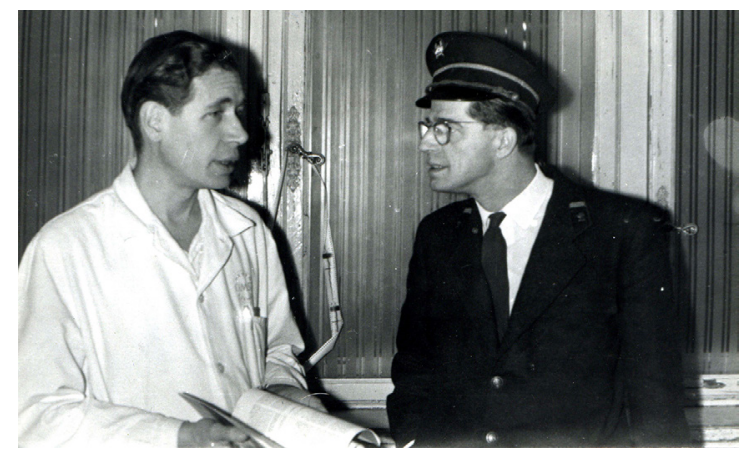

Figure 7. The Chief Medical Officer and Founder of SAS, Thomas Felkai MD PhD (Right) Discussing Medical Protocol With Aurel Gabor $\mathrm{MD} \mathrm{PhD}$, Senior Internist of the National Emergency Service Hospital. cardiac problem and hospital admission was around 8 hours. ${ }^{16}$ The main reason for circulation stopping was early rhythm disturbances. When some simply-performed methods were elaborated (defibrillation ${ }^{17}$ with cardiopulmonary resuscitation, ${ }^{18}$ and a cardiac pacemaker ${ }^{19}$ ), the possibility of on-site treatment was given. A skilled team was required on the scene of the attack to provide first therapy (mainly treatment of the early rhythm disturbances and later for thrombolytic interventions) to the cardiac patient within that time limit now known as the "golden hour." To reduce the number of sudden cardiac deaths, a mobile coronary care unit (MCCU) was developed at the Royal Victoria Hospital in Belfast in $1966,{ }^{20}$ parallel to the development of coronary intensive care units in hospitals worldwide. Encouraged by the

Table 2. Entry to Service of All-Purpose Ambulances by Countries, Their Equipment, and Their Medical Team

\begin{tabular}{|c|c|c|c|c|c|}
\hline Town, Country & Vehicle Name & $\begin{array}{l}\text { Triggering Factor or Aim of } \\
\text { Invention }\end{array}$ & $\begin{array}{l}\text { Date of the First } \\
\text { Appearance }\end{array}$ & Staff & Equipment \\
\hline Hungary, Budapest & $\begin{array}{l}\text { Rohamkocsi, ROKO } \\
\text { (storm ambulance } \\
\text { vehicle) }\end{array}$ & $\begin{array}{l}\text { Increase in electric } \\
\text { accidents due to forced } \\
\text { industrialization, and growing } \\
\text { number of cardiac patients }\end{array}$ & 29 March 1954 & $\begin{array}{l}\text { Emergency } \\
\text { physician, } \\
\text { ambulancemen, and } \\
\text { drivers }\end{array}$ & $\begin{array}{l}\text { Oxygen, iron-lung, ECG, } \\
\text { infusions, drugs, Cramer } \\
\text { tire }\end{array}$ \\
\hline $\begin{array}{l}\text { West Germany, } \\
\text { Heidelberg }\end{array}$ & Klinomobil & $\begin{array}{l}\text { Increase in traffic accidents } \\
(20 \%)\end{array}$ & 16 February 1957 & $\begin{array}{l}\text { Surgeon and/or } \\
\text { anesthesiologist, } \\
\text { paramedic, driver, } 7 \\
\text { persons for an on- } \\
\text { the-spot operation }\end{array}$ & $\begin{array}{l}\text { Equipment for operation } \\
\text { of a trauma case and } \\
\text { anesthesia }\end{array}$ \\
\hline $\begin{array}{l}\text { West Germany, } \\
\text { Köln }\end{array}$ & NAW & Increase in traffic accidents & 3 June 1957 & $\begin{array}{l}\text { Surgeon, later } \\
\text { paramedics, driver } \\
\text { (ambulance comes } \\
\text { later [rendez-vous } \\
\text { system]) }\end{array}$ & $\begin{array}{l}\text { Anesthesia circuit part } \\
\text { with suction, intubation } \\
\text { and surgical instruments, } \\
\text { a portable ventilator, } \\
\text { blood replacement fluids, } \\
\text { and medications }\end{array}$ \\
\hline $\begin{array}{l}\text { Salon da } \\
\text { Provence, France }\end{array}$ & SMUR & Increase in traffic accidents & 1957 June 22 & $\begin{array}{l}\text { Surgeon, driver, } \\
\text { nurse }\end{array}$ & $\mathrm{N} / \mathrm{A}$ \\
\hline $\begin{array}{l}\text { Leningrad, Soviet } \\
\text { Union }\end{array}$ & $\begin{array}{l}\text { Special ambulance } \\
\text { bus }\end{array}$ & On-site reanimation & 1957 & $\begin{array}{l}\text { Physician, nurse, } \\
\text { and driver }\end{array}$ & $\begin{array}{l}\text { Pneumatic cuff (shock } \\
\text { prevention), arterial } \\
\text { infusion kit, and mobile } \\
\text { electric respiratory } \\
\text { stimulator }\end{array}$ \\
\hline $\begin{array}{l}\text { Heidelberg, West } \\
\text { Germany }\end{array}$ & URW & $\begin{array}{l}\text { All-purpose emergency } \\
\text { treatment on street }\end{array}$ & 1959 & N/A & $\mathrm{N} / \mathrm{A}$ \\
\hline $\begin{array}{l}\text { Northern Ireland, } \\
\text { Belfast }\end{array}$ & MCCU & $\begin{array}{l}\text { Prevention of pre-hospital } \\
\text { cardiac arrest }\end{array}$ & 1966 & $\begin{array}{l}\text { Cardiologist, nurse, } \\
\text { and driver }\end{array}$ & $\begin{array}{l}\text { ECG monitor, defibrillator, } \\
\text { and pacemaker }\end{array}$ \\
\hline UK, Brighton & $\begin{array}{l}\text { Mobile coronary } \\
\text { ambulance, MCCU, } \\
\text { and resuscitation } \\
\text { ambulance }\end{array}$ & $\begin{array}{l}\text { Prevention of pre-hospital } \\
\text { cardiac arrest }\end{array}$ & 1968 & $\begin{array}{l}\text { Paramedics and } \\
\text { driver }\end{array}$ & $\begin{array}{l}\text { Defibrillator, iv kit, and } \\
\text { intubation set }\end{array}$ \\
\hline UK, Brighton & $\begin{array}{l}\text { Mobile coronary } \\
\text { ambulance, MCCU, } \\
\text { and resuscitation } \\
\text { ambulance }\end{array}$ & $\begin{array}{l}\text { Prevention of pre-hospital } \\
\text { cardiac arrest }\end{array}$ & 1968 & $\begin{array}{l}\text { Paramedics and } \\
\text { driver }\end{array}$ & $\begin{array}{l}\text { Defibrillator, iv kit, and } \\
\text { intubation set }\end{array}$ \\
\hline USA, New York & MCCU & $\begin{array}{l}\text { For decreasing the number of } \\
\text { myocardial death }\end{array}$ & 1978 & $\begin{array}{l}\text { Attending physician, } \\
\text { nurse, driver, } \\
\text { emergency room } \\
\text { nurse }\end{array}$ & $\begin{array}{l}\text { Portable battery powered } \\
\text { defibrillator/ monitor; } \\
\text { a battery-powered } \\
\text { electrocardiograph, I.V. } \\
\text { kit, resuscitation/ oxygen } \\
\text { kit and a drug kit }\end{array}$ \\
\hline
\end{tabular}

Abbreviations: SMUR, Service Mobile d'Urgence et de Réanimation; NAW, notfallartzwagen; URW, Unfall rettungswagen; 
Table 3. Medical Tools and Devices Then and Now

\begin{tabular}{|c|c|c|}
\hline Tools and Materials Used for & In 1954 & In 2014 \\
\hline Oxygenisation & Oxygen bottle (10 L) & Oxygen bottle (10 L) \\
\hline Volume replacement & $\begin{array}{l}\text { Glass infusion bottle with homemade } \\
\text { plastic kit }\end{array}$ & Plastic bag infusion + disposable kit; \\
\hline Infusion technique & Subcutan (!), later via cubital vein & Intraosseal kit; infusion pump, central venous access \\
\hline Artificial ventillation & Iron lung (temporarily) & Mobile ventilator (different ventilation modes), capnograph-controll \\
\hline Plasmaexpansion & $6 \times 240 \mathrm{~mL}$. human defibrinated plasma & Dextran, HAES, Ringer solution \\
\hline Fracture fixation device & Cramer - tire (junk) & Vacuum bed, SAM-splint \\
\hline Vertebral fixation device & Wooden stretcher & Vacuum bed, scoop-stretcher \\
\hline Cardiac monitoring & 1 channel mobile ECG, photosensitive strip & 12 channels EKG device, LED display \\
\hline Airway maintenance & Surgical kit for tracheotomy & Intubation kit (adult and children) \\
\hline Protective clothing & Gas-mask, helmet & HIV defence kit ( disposable clothes and glasses) \\
\hline Delivery & Delivery kit & Delivery kit and infant resuscitation kit \\
\hline Anaesthesia & chlorethilaether & Anaestheticums and muscle-relaxant \\
\hline Airway suction & $50 \mathrm{~mL}$. syringe & Electric and manual suction devices \\
\hline Manual ventillation & oxymat elekrtostimulator & Ballon for manual ventilation \\
\hline Defibrillator & $X$ & 6 channel defibrillator-cardioverter with monitor \\
\hline Pacemaker & X & Together with defibrillator-monitor, intravenous or percutan \\
\hline Pain-killer & $\begin{array}{l}\text { Morphine + chlorpromasine + pipolphen } \\
\text { (lytic coctail) }\end{array}$ & Fentanyl, morphine, pethidine \\
\hline
\end{tabular}

success in Belfast, the idea of prehospital cardiac care spread to other UK cities (e.g., Brighton, 1968 ${ }^{21}$ ) and other countries. The first cardiac ambulance in the United States was stationed at St. Vincent's Hospital in New York, NY. It began its activity in 1968 and was modeled after the Belfast program. ${ }^{22}$

From the 1950s to the 1970s, the use of special ambulance vehicles, first intervention cars, and other special doctors' vehicles was implemented throughout the world, from Leningrad (Saint Petersburg, szkorij pomoscs, 1957) to Brescia (Centro mobile de reanimazione, 1966). Special teams were established in New Delhi (Flying Doctor Squad, 1969), Copenhagen (Cardiomobil, 1974), and Australia ${ }^{23}$ (Coronary Ambulance, 1972). ${ }^{24}$ In Japan, the first mobile cardiac ambulance was created in 1972. The fascinating history of the doctor-manned special ambulances still has many undeveloped facts; therefore further research is badly needed.

\section{Conclusion}

While the Hungarian special ambulance served as an outpost emergency room, its staff treated traumatic and nontraumatic emergency cases and acquired some first-hand medical experience in on-site emergency treatment. The most important observation was the value of prehospital care. The sooner the patient received therapy on-site, the better his/her condition was when he/she arrived at the hospital. Similarly, volume replacement (by plasma or a plasma-expander agent) proved to be an excellent method for restoring circulation and preventing shock. Shock prevention medications were also developed, applied as the famous "lytic cocktail," a mixture of pethidine and chlorpromazine (or later, promethasin). Artificial ventilation, after on-site orotracheal intubation, could be performed even inside a moving vehicle. Stabilizing the patient's vital functions on-site is crucial both in trauma cases (preventing the development of shock) and in cardiac patients (early treatment of arrhythmias). Based on these experiences, the idea of transportation trauma was elaborated. ${ }^{25}$ Unfortunately, because of the limited possibilities for publication in Eastern-European countries at that time, the idea seemed to be lost. Finally, however, Cowley's expression "the golden hour" was accepted worldwide ${ }^{26}$ and settled into the basic theories of emergency medicine. The tools, medical interventions, and medicines used long ago in emergency practice are trivial, but they were the forerunners of the hitech emergency tools and devices with which even ordinary ambulances are now equipped (Table 3 ).

The Hungarian initiative of applying a multidisciplinary approach to the ambulance service proved viable, while the emergency vehicles, with their unilateral treatment-ability (just cardiac care or trauma care) did not satisfy the complex

\section{Review Highlights}

\section{What Is Already Known?}

The time factor in emergencies is vital from the point of view of survival rate. The time factor could be reduced considerably if treatment began on-site. There were two ways to provide treatment on-site: a dedicated ambulance for trauma cases (Germany), and a dedicated ambulance for cardiac care (the United Kingdom and the United States).

\section{What This Study Adds?}

The current study points out that the most effective onsite intervention is the multipurpose ambulance equipped with medical devices good for both trauma and cardiac cases and an emergency doctor on board. This kind of ambulance entered into service as early as 1954 . 
demand for rescue/emergency activity in subsequent decades. The recent literature states that the "all-ALS type" rescue service (the multipurpose, sole-provider, all-advanced life support ambulance service) proved extremely effective in the field of prehospital emergency treatment. ${ }^{27}$ This statement is proven true by the more than 60 years of the Hungarian SAS.

\section{Authors' Contributions}

Both authors contributed equally to this study.

\section{Conflict of Interest Disclosures}

None declared.

\section{Ethical Approval}

Not applicable.

\section{Funding/Support}

None received.

\section{References}

1. Lowell NC. Trauma analysis in paleopathology. Yearbook Physical Antropology. 1997;40:139-170.

2. Anderson T, Carter AR. An archaeological example of medieval trauma. J Paleopathol.1994;6(3):145-150.

3. Felkai P. First traces of resuscitation attempts in ancient Egypt. Orv Hetil. 1986;127(28):1709-1712.

4. Brewer LA 3rd. Baron Dominique Jean Larrey (1766-1842). Father of modern military surgery, innovater, humanist. J Thorac Cardiovasc Surg. 1986;92(6):1096-1098.

5. Bell RC. The Ambulance: A History. McFarland: Jefferson NC; 2009:146.

6. Pulmotor fire Squad Now. New York Times. January 19,1915:6.

7. Felkai T. Fehér kocsin kék fény (Blue Light on a White Car). Budapest: Medicina; 1966

8. Stout J, Pepe PE, Mosesso VN Jr. All-advanced life support vs tieredresponse ambulance systems. Prehosp Emerg Care. 2000;4(1):1-6.

9. Sefrin P, Kuhnigk H. Stellung des Notarztes im Rettungsdienst (The position of the emergency physician in the emergency medical service). Anasthesiol Intensivmed Notfallmed Schmerzther. 2006;41(1):2-8. doi:10.1055/s-2006-924965.

10. Fischer $M$, Krep H, Wierich D, et al. Comparison of the emergency medical services systems of Birmingham and Bonn: process efficacy and cost effectiveness. Anasthesiol Intensivmed Notfallmed Schmerzther. 2003;38(10):630-642. doi:10.1055/s-2003-42507.

11. Langhelle A, Lossius HM, Silfvast $\mathrm{T}$, et al. International EMS Systems: the Nordic countries. Resuscitation. 2004;61(1):9-21. doi:10.1016/j.resuscitation.2003.12.008.
12. Anästhesiologische Klinik. http://www.klinikum.uni-heidelberg. de/Notaerztliche-Taetigkeit.8240.0.html. Accessed June 7, 2014.

13. Jochen P. Qualität notärztlicher Diagnosen: Ein Vergleich von Fachärzten und Weiterbildungsassistenten der Anästhesie. Inaugural-Dissertation zur Erlangung der Doktorwürde an der Medizinischen Fakultät der Friedrich-Alexander-Universität. Erlangen-Nürnberg; 2010.

14. Coirier R. La politique Francaise dans le domaine des secours d'urgence. 3rd ed. in: International Symposium van de Dringende Hulpverlening. Brügge; 1973.

15. Bainton CR, Peterson DR. Deaths from Coronary Heart Disease in Persons Fifty Years of Age and Younger. N Engl J Med. 1963;268(11):569-575. doi:10.1056/nejm196303142681102.

16. McNeilly RH, Pemberton J. Duration of last attack in 998 fatal cases of coronary artery disease and its relation to possible cardiac resuscitation. Br Med J. 1968;3(5611):139-142. doi:10.1136/ bmj.3.5611.139.

17. Zoll PM. Resuscitation of the heart in ventricular standstill by external electric stimulation. N Engl J Med. 1952;247(20):768771. doi:10.1056/nejm195211132472005.

18. Kouwenhoven WB, Jude JR, Knickerbocker GG. Closed-chest cardiac massage. JAMA. 1960;173:1064-1067. doi:10.1001/ jama.1960.03020280004002.

19. Chardack WM, Gage AA, Greatbatch W. A transistorized, selfcontained, implantable pacemaker for the long-term correction of complete heart block. Surgery. 1960;48:643-654.

20. Pantridge JF, Geddes JS. A mobile intensive-care unit in the management of myocardial infarction. Lancet. 1967;2(7510):271273. doi:10.1016/S0140-6736(67)90110-9.

21. Chamberlain D, Baskett $P$, Willis $M$. From invalid transport corps to paramedic practitioners. Barts and the London Chronicle. 2004;6:18-21.

22. Eisenberg MS, Pantridge JF, Cobb LA, Geddes JS. The revolution and evolution of prehospital cardiac care. Arch Intern Med. 1996;156(15):1611-1619. doi:10.1001/ archinte.1996.00440140021002.

23. O'Rourke M. Modified coronary ambulances. Med J Aust. 1972;1:875-878.

24. Felkai T. A mentés kialakulásának fejlődéstörténeti elemzése. Kandidátusi disszertáció (The analysis of the development of rescue PhD tractate). Budapest: 1977.

25. Felkai T. Some consideration on shock in the rescue practice [A shock-kérdés a mentőgyakorlatban]. Orvosi Hetilap. 1956;97(15):404-408.

26. Cowley RA, Hudson F, Scanlan E, et al. An economical and proved helicopter program for transporting the emergency critically ill and injured patient in Maryland. J Trauma. 1973;13(12):1029-1038. doi:10.1097/00005373-197312000-00001.

27. Stout J, Pepe PE, Mosesso VN Jr. All-advanced life support vs tieredresponse ambulance systems. Prehosp Emerg Care. 2000;4(1):1-6. doi:10.1080/10903120090941542. 